\title{
Vascular Remodeling in Pulmonary Hypertension
}

\author{
Larissa A Shimoda and Steven S. Laurie \\ Division of Pulmonary and Critical Care Medicine, Department of Medicine, Johns Hopkins \\ School of Medicine, Baltimore, MD 21224
}

\begin{abstract}
Pulmonary hypertension is a complex, progressive condition arising from a variety of genetic and pathogenic causes. Patients present with a spectrum of histologic and pathophysiological features, likely reflecting the diversity in underlying pathogenesis. It is widely recognized that structural alterations in the vascular wall contribute to all forms of pulmonary hypertension. Features characteristic of the remodeled vasculature in patients with pulmonary hypertension include increased stiffening of the elastic proximal pulmonary arteries, thickening of the intimal and/or medial layer of muscular arteries, development of vaso-occlusive lesions and the appearance of cells expressing smooth muscle specific markers in normally non-muscular small diameter vessels, resulting from proliferation and migration of pulmonary arterial smooth muscle cells and cellular trans-differentiation. The development of several animal models of pulmonary hypertension has provided the means to explore the mechanistic underpinnings of pulmonary vascular remodeling, although none of the experimental models currently used entirely replicates the pulmonary arterial hypertension observed in patients. Herein, we provide an overview of the histological abnormalities observed in humans with pulmonary hypertension and in preclinical models and discuss insights gained regarding several key signaling pathways contributing to the remodeling process. In particular, we will focus on the roles of ion homeostasis, endothelin-1, serotonin, bone morphogenetic proteins, Rho kinase and hypoxia-inducible factor 1 in pulmonary arterial smooth muscle and endothelial cells, highlighting areas of cross-talk between these pathways and potentials for therapeutic targeting.
\end{abstract}

\section{Introduction}

Pulmonary hypertension (PH) is a complex, progressive, and often fatal condition. Although uniformly defined by the hemodynamic criteria of resting pulmonary arterial pressure $\left(\mathrm{P}_{\mathrm{pa}}\right)$ $225 \mathrm{~mm} \mathrm{Hg}$, PH can arise from a variety of etiologies and patients present with a spectrum of severities and symptoms. In 2008, discussions at the $4^{\text {th }}$ World Symposium on Pulmonary Hypertension in Dana Point led to a new classification strategy dividing PH into five major categories: 1) pulmonary arterial hypertension $(\mathrm{PAH})$, including idiopathic, heritable and drug/toxin-induced PH; 2) PH due to left heart disease; 3) PH due to interstitial lung diseases and/or hypoxia, including high-altitude and chronic obstructive pulmonary disease (COPD); 4) chronic thromboembolic PH (CTEPH); and 5) PH with unclear and/or multifactorial origin, including hematologic and systemic disorders [1,2].

While the exact causes of PH remain under investigation, and are likely to vary with the underlying pathogenic or genetic cause, it is widely recognized that the hallmarks of all forms of PH are sustained vasoconstriction and vascular remodeling. Remodeling of pulmonary blood vessels is characterized to varying degrees by thickening of the intimal

Address for Correspondence: Larissa A. Shimoda, PhD, Division of Pulmonary and Critical Care Medicine, Johns Hopkins University, 5501 Hopkins Bayview Circle, JHAAC 4A.52, Baltimore, MD 21224, 410-550-1013, FAX: 410-550-2612, shimodal@welch.jhu.edu. 
and/or medial layer of muscular vessels and the appearance of cells expressing smooth muscle specific markers in pre-capillary arterioles (distal muscularization), resulting from proliferation and migration of pulmonary arterial smooth muscle cells (PASMCs) and possibly cellular trans-differentiation (i.e., endothelial-mesenchymal transformation) [3, 4]. Development of vaso-occlusive lesions, involving PASMCs, endothelial cells (ECs) and possibly cells of non-vascular origin, occurs in some severe forms of PAH $[5,6]$. The greatest influence on pulmonary vascular resistance (PVR) results mainly from changes in small arterioles; however, decreased compliance (i.e., increased stiffness) in the elastic proximal pulmonary arteries may also increase right ventricular afterload [7-9].

The relative contributions of reactivity and remodeling to elevated $\mathrm{P}_{\mathrm{pa}}$ varies (Table 1). Although remodeling was originally believed to cause inward narrowing of the vascular lumen and "fixed" constriction in all forms of $\mathrm{PH}$, evidence now suggests that in many instances remodeling occurs in an outward fashion without luminal encroachment and that much of the "fixed" component was due to incomplete relaxation [10-12]. Under these conditions (i.e., in hypoxia-induced $\mathrm{PH}$ ), remodeling with increased muscularization likely contributes to elevated PVR via hyperreactivity to constricting agents. In contrast, intimal narrowing and vaso-occlusion is a factor in PAH. The focus of this review will be to highlight our evolving understanding of vascular remodeling in $\mathrm{PH}$, with a focus on PASMCs and ECs, discuss mechanisms contributing to the remodeling process, and highlight areas where investigation is needed and therapeutic potential exists.

\section{Evidence of Remodeling in Humans with Pulmonary Hypertension}

Owing to the difficulty in visualizing and measuring vascular wall changes in patients, most evidence for remodeling comes from post-mortem or post-operative tissue specimens. Histological analysis of the pulmonary vasculature from South American children born and raised at altitude revealed muscularization of small arteries situated at the alveolar ducts and sacs, which was not observed in children at sea level [13]. In adults, high-altitude natives of the Peruvian Andes exhibited right ventricular enlargement and increased PVR [14, 15] thought to be due in part to vascular remodeling since administration of oxygen failed to completely reverse the elevated $P_{p a}$ and PVR [14]. This supposition was corroborated by data from post-mortem studies demonstrating medial hypertrophy, PASMC hyperplasia and muscle extension into distal arterioles, with considerable variability noted between individuals [16-19]. In contrast, the native high-altitude population of Tibet does not have increased smooth muscle [20, 21]. Given that Tibetans have resided at high altitude for longer than any other population, the difference in vascular response may be due to variations in genetic adaptation.

Histological evidence of vascular remodeling is also available from tissues derived from the $\mathrm{PH}$ patient population. Tissue from COPD patients obtained post-mortem or following lung resection exhibited arteriolar muscularization, increased intimal thickness and reduced lumen area independent of $\mathrm{P}_{\mathrm{pa}}$ or responsiveness to oxygen [22-24]. However, intimal changes were also observed in some non-hypoxemic smokers and in mild COPD patients without $\mathrm{PH}[25,26]$, leading to questions regarding the contribution of remodeling to $\mathrm{PH}$ in this population. In PAH patients, early abnormalities include medial hypertrophy, adventitial thickening, and extension of muscle, with vaso-occlusive lesions developing at later stages $[5,6]$.

\section{Evidence of Remodeling in Animal Models of Pulmonary Hypertension}

In order to better understand functional and structural changes in the hypertensive lung and to begin to identify underlying causes, several animal models of PH have been utilized. Unfortunately, no single model perfectly replicates human PAH. Nevertheless, these models 
provide opportunities for studying the development, progression and mechanistic underpinnings of $\mathrm{PH}$ and evaluating potential therapeutic treatments.

\section{Chronic Hypoxia as an Inciting Factor}

During the early $20^{\text {th }}$ century, the recognition of brisket disease in cattle provided one of the first insights into the cardiac problems that develop due to $\mathrm{PH}$ [27]. Described as the 'dropsy' condition, cattle living in the high mountains (>8,000 ft) of Colorado, especially those shipped from lower altitudes, suffered from edema surrounding the brisket, or lower chest, and enlarged, dilated, and 'flabby' hearts [27]. Altitude was identified as the primary cause of heart failure [27], and in the intervening years, the bovine model of hypoxic PH has been used to explore vascular changes occurring with chronic hypoxia $(\mathrm{CH})$. Extensive vascular remodeling was observed, characterized by collagen deposition, thickened adventitia, increased medial thickness, extension of muscle down to precapillary arterioles and intimal narrowing in small pulmonary arteries [4, 28], with newborn calves appearing even more susceptible than adult cattle [29].

Rats and mice produce predictable and reproducible features of $\mathrm{PH}$ after just a few weeks in a hypoxic environment (typically $10 \% \mathrm{O}_{2}$ ) and, due to their inbred backgrounds, small size, and the availability of genetically manipulated animals, have become the most common species used in the $\mathrm{CH}$ model. In general, rats exhibit substantial increases in $\mathrm{P}_{\mathrm{pa}}$ and right ventricular mass, accompanied by increased vascular wall thickness, due to PASMC hypertrophy and hyperplasia, and distal muscularization [4, 30]. Initial imaging studies suggested that remodeling reduced luminal diameter and resulted in rarefaction, or vascular pruning $[31,32]$. However, these observations may have reflected incomplete release of vasoconstriction or variable perfusion $[11,33,34]$, as remodeling in this model appears to occur in an outward manner and is associated with angiogenesis [35].

Mice also develop PH upon exposure to $\mathrm{CH}$, although PASMC proliferation is minimal [4, 36, 37]. The most consistent finding in mice is muscularization of distal vessels and thickening and functional stiffening of proximal, conduit arteries [4]. Strain-dependent differences in hypoxia-induced PH have been noted in mice; C57BL6 respond moderately while other strains exhibit little to no response [4]. Variability between species also exists. For example, mice exhibit less remodeling in response to $\mathrm{CH}$ than rats and humans, all of which respond less than neonatal calves, even when exposed to more severe hypoxic stimuli $[29,38]$. The presence of a complete layer of PASMCs in peripheral arteries of normotensive bovine, which is absent in normotensive humans [39] or rodents, may account for some of these differences. Nonetheless, the phenotype observed in $\mathrm{CH}$ models is consistent with PH that develops in humans as a result of high altitude, as vaso-occlusive lesions are not observed and return to a normoxic environment reverses hypoxia-induced $\mathrm{PH}$ in all animal models.

\section{Chronic Hypoxia as a Second Hit}

Fawn-hooded rats spontaneously develop $\mathrm{PH}$ with age, but exposure to mild $\mathrm{CH}$ accelerates the process and induces a severe form of PH not seen in other strains [40, 41]. Extension of muscle into peripheral vessels and medial hypertrophy of proximal arteries was observed, as was reduced vessel filling in imaging studies [41], but whether this reflected development of vaso-occlusive lesions, which have not been reported, or severe vasoconstriction [11] is unclear. A key difference in Fawn-hooded rats is development of systemic hypertension, which is not typically associated with PAH in humans [4, 40, 41].

An even more severe rat model of $\mathrm{PH}$ was developed using a single dose of the vascular endothelial growth factor (VEGF) receptor inhibitor, SU5416, followed by exposure to $\mathrm{CH}$. 
VEGF receptor inhibition initially causes EC apoptosis; subsequent hypoxic exposure may stimulate proliferation of a subset of ECs that are apoptosis-resistant, causing occlusive lesions reminiscent of PAH in humans and PASMC proliferation [42, 43]. Unlike $\mathrm{CH}$ alone, $\mathrm{PH}$ induced by the combination of SU5416 and hypoxia is irreversible even after return to normoxia. Recently, injections of SU5416 during CH was used to create a murine model exhibiting increased arterial muscularization and collagen deposition in the media and adventitia [44]. These mice also developed vaso-occlusive lesions and ultimately right heart dysfunction. In contrast to the rat model, however, mice required multiple injections of SU5416 and vascular remodeling and PH began to resolve upon return to normoxia [44]. The reason for the difference between the rat and murine models is unknown.

\section{Monocrotaline}

First described $>40$ yrs ago [45], PH develops following ingestion of seeds from the plant Crotalaria spectabilis, whereby monocrotaline (MCT) is metabolized in the liver into a toxic substance (monocrotaline pyrrole) that causes inflammation and EC injury [4]. Rats are most commonly used in this model since mice cannot convert MCT to its active form [46]. PH develops within 2-3 weeks, and while occlusive lesions are not observed, muscle content increases in arteries of all sizes [47]. The MCT model is widely used due to ease of inducing severe $\mathrm{PH}$ with a single injection, but the lack of vascular occlusions, concurrent pulmonary venous and hepatic dysfunction and the fact that $>30$ agents effectively reverse MCTinduced PH [4] raise questions as to the relevance of MCT as model for human PAH. Thus, attempts have been made to modify the model to more accurately reflect PAH. When MCTinduced wall injury/EC dysfunction is combined with hemodynamic changes induced by pneumonectomy, intimal changes occur, including development of distal vaso-occlusive lesions, that are not present when MCT is used alone [48, 49].

\section{Mice Overexpressing Serotonin Transporter}

Serotonin, or 5-hydroxytryptamine (5-HT), is involved in the development of PAH associated with use of diet medications (aminorex or fenfluramines) which increase 5-HT availability. 5-HT enters PASMCs via a membrane serotonin transporter (SERT), which also mediates efflux of 5-HT [50]. SERT expression is upregulated in PASMCs from PAH patients [50] and increased 5-HT transport into PASMCs enhances, and SERT inhibition prevents, proliferation $[51,52]$. In male mice, SERT deficiency protected against $\mathrm{CH}$ induced remodeling whereas SERT over-expression had no significant effect $[50,53]$. In contrast, SERT overexpression induced medial thickening and distal muscularization in normoxic female mice and accentuated the effect of hypoxia [50, 53], providing the only known mouse model that mimics the disproportionate female predominance seen in human PAH.

\section{Murine Models with BMPR2 Mutations}

The transforming growth factor $\beta$ (TGF- $\beta$ ) superfamily is composed of $>40$ structurally similar cytokines, including TGFs and bone morphogenetic proteins (BMPs). BMPs are produced as inactive precursors and cleaved to create a mature ligand that activates cell surface complexes comprised of type I and type II receptors [54]. Receptor activation leads to internal signaling of nuclear transcription factors to upregulate or suppress transcription of target genes [55]. While mutations in the gene encoding one of these receptors, the bone morphogenetic protein receptor type 2 (BMPR2), are found in the majority of heritable PAH cases [56] and $\sim 25 \%$ of idiopathic PAH patients [57], why only $\sim 20 \%$ of individuals with heterozygous BMPR2 mutation develop PAH remains unknown and suggests a second "hit" is required [58]. All known BMPR2 mutations lead to decreased receptor levels or expression of dysfunctional protein [59]. Since normally functioning BMPR2 receptors 
serve as an internal brake against the TGF- $\beta$ system, loss of BMPR 2 activation favors greater TGF- $\beta$ signaling and PASMC proliferation [58].

Transgenic mice with heterozygous BMPR2 mutations exhibit variability in PH morphology, with some developing increased wall thickness compared to wild type mice [60]. Right ventricular pressure was similar in normoxic mice and mice subjected to $\mathrm{CH}$ for 3 wks [61, 62], with mild disease presentation when $\mathrm{CH}$ was extended to 5 weeks [62], suggesting that the mutation alone may not be sufficient to generate $\mathrm{PH}$. Mice expressing a conditional smooth muscle-specific BMPR2 dominant-negative mutant developed PH with increased medial thickness and muscularization of distal pulmonary arteries, but no intimal lesions [63]. Clearly, these models present complex morphologies and probably lack additional genetic or environmental cofactors present in human PAH.

\section{Mechanisms Involved in Pulmonary Vascular Remodeling}

While a variety of animal models have been utilized to identify mechanisms responsible for development of $\mathrm{PH}$ and test potential treatments, none perfectly captures the pulmonaryspecific characteristics of severe human PAH. Models incorporating multiple insults appear to more closely reflect human $\mathrm{PH}$, although given the multiple classifications no single model can match all forms of the disorder. However, these models have provided valuable insight into the signaling pathways contributing to vascular remodeling (Fig. 1), with the majority of work centered on PASMCs and ECs.

\section{The Role of $\mathrm{K}^{+}$channels}

One of the earliest studies examining functional changes in PASMCs during $\mathrm{CH}$ revealed that rat cells were depolarized [64], a finding confirmed in other species (reviewed in [65]). PASMCs from humans with PAH are also depolarized [66]. Reduced $\mathrm{K}^{+}$channel expression and activity were subsequently identified as contributing factors to depolarization in hypoxic PH [65, 67, 68], Fawn-hooded rats [69] and human PAH [70, 71]. Experimental manipulations that augmented PASMC K ${ }^{+}$channel expression/activity reduced remodeling in hypoxic animals $[68,72]$ and increased apoptosis in PASMCs from PAH patients [71]. Thus, modulating $\mathrm{K}^{+}$channel activity modifies PASMC growth; however, the exact mechanism by which reduced $\mathrm{K}^{+}$channel activity and/or depolarization causes remodeling is still debated. Depolarization was initially hypothesized to drive activation of voltagegated calcium channels (VGCC) and calcium influx, but VGCC inhibitors have little effect on PASMCs from hypoxic animals [73-75] or the majority of patients with PH [76, 77]. Instead, increased intracellular $\mathrm{K}^{+}$was proposed to promote remodeling by conferring resistance to apoptosis [67].

Restoration of $\mathrm{K}^{+}$channel activity/expression provides an attractive target for therapeutics aimed at reducing remodeling in PAH. Animal studies using dehydroepiandrosterone, a steroid hormone that, among other actions, opens $\mathrm{K}^{+}$channels, reduced remodeling in $\mathrm{CH}$ rats [78]. Similar results were reported in hypoxic and MCT-treated animals receiving dichloroacetate, a metabolic modulator that also increases the expression of $\mathrm{K}^{+}$channels $[68,79]$. Whether the beneficial effects of either drug on remodeling were due to actions on $\mathrm{K}^{+}$channels or other targets remains to be determined; however, based on promising preclinical data, the use of dichloroacetate to treat PAH is currently in Phase 1 clinical trials in Canada.

\section{Elevations in Intracellular $\mathrm{Ca}^{2+}$ Concentration}

Increased intracellular calcium concentration $\left(\left[\mathrm{Ca}^{2+}\right]_{\mathrm{i}}\right)$ is required for PASMC growth $[80$, 81] and migration [82] and has been documented in cells from hypoxic [65] and MCTtreated [83] animals and patients with PAH [80, 84]. VGCCs do not appear to contribute to 
elevated basal PASMC $\left[\mathrm{Ca}^{2+}\right]_{\mathrm{i}}$ in PH [73-75], but can be activated by agonists $[85,86]$ and contribute to stimulated proliferation [87]. Thus, VGCCs may participate in the remodeling process in $\mathrm{PH}$, particularly in the presence of excessive growth factors.

Accumulating data indicates that elevated basal PASMC $\left[\mathrm{Ca}^{2+}\right]_{\mathrm{i}}$ occurs primarily via upregulation of canonical transient receptor potential (TRPC) proteins, which comprise $\mathrm{Ca}^{2+}$-permeable nonselective cation channels (NSCCs) [65]. Unlike VGCCs, NSCCs are not activated by depolarization, but can be modulated by phosphorylation, receptor activation or store depletion [88-90]. Increased abundance of TRPC proteins was observed in PASMCs derived from animals subjected to $\mathrm{CH}[74,75]$ and $\mathrm{PAH}$ patients [91, 92]. Decreasing the activity of NSCCs, either pharmacologically or by RNA silencing, reduced $\left[\mathrm{Ca}^{2+}\right]_{\mathrm{i}}[74,75]$ and proliferation [91, 92] in PH PASMCs. Consistent with these findings, a gain-of-function single nucleotide polymorphism in TRPC6 was recently identified in patients with PAH [93].

Selective inhibitors for NSCCs have not been tested in PH. However, sildenafil, a phosphodiesterase type 5 inhibitor widely used in the treatment of $\mathrm{PAH}$, reduced $\left[\mathrm{Ca}^{2+}\right]_{\mathrm{i}}$ and TRPC expression in PASMCs from chronically hypoxic animals [94], and also attenuated PASMC proliferation [95, 96] and prevented remodeling in MCT-treated [96] and hypoxic [97] rats. Due to the difficulty in monitoring vascular wall changes in the clinical population, whether sildenafil, alone or in combination with other standard treatments, alters $\mathrm{Ca}^{2+}$ signaling and/or reverses or slows pulmonary vascular remodeling in PAH patients is unknown.

Once $\left[\mathrm{Ca}^{2+}\right]_{\mathrm{i}}$ rises, several downstream signal transduction pathways and transcription factors are activated that could be involved in PASMC proliferation (reviewed in [98]). In particular, $\mathrm{Ca}^{2+}$ activates nuclear factor of activated T-cells (NFAT), which in turn reduces $\mathrm{K}^{+}$channel expression and increases proliferation [71], providing a link between alterations in $\left[\mathrm{Ca}^{2+}\right]_{\mathrm{i}}$, dysregulated $\mathrm{K}^{+}$channel expression/activity and PASMC growth. Accordingly, remodeling was reversed when NFAT was pharmacologically inhibited [71].

PASMC migration is also known to be induced by hypoxia $[99,100]$ and modulated by changes in $\left[\mathrm{Ca}^{2+}\right]_{\mathrm{i}}[101]$, [82], but even so, the exact mechanisms controlling PASMC migration in $\mathrm{PH}$ have yet to be deciphered. During hypoxia, $\mathrm{Ca}^{2+}$-dependent increases in the expression of aquaporin 1 (AQP1), a membrane water channel, are required for migration of PASMCs [82]. Increased AQP1 levels may result in localized control of water flux across the cell membrane, possibly allowing for directed cell movement [102]. Alternatively, AQP1 may participate in cytoskeletal rearrangement [103], which is required for cell migration. In addition to AQP1, recent data also implicates roles for microRNAs [99] and RhoB [100] in hypoxia-induced PASMC migration, although whether these factors are upstream, downstream or unrelated to changes in $\left[\mathrm{Ca}^{2+}\right]_{\mathrm{i}}$ is unknown.

In contrast to PASMCs, little work has examined $\left[\mathrm{Ca}^{2+}\right]_{\mathrm{i}}$ in ECs during PH. Culture of human pulmonary ECs under hypoxic conditions increased basal $\left[\mathrm{Ca}^{2+}\right]_{\mathrm{i}}$ and TRPC4 expression [104], suggesting that perturbations in $\mathrm{EC}\left[\mathrm{Ca}^{2+}\right]_{\mathrm{i}}$ signaling could occur during $\mathrm{PH}$ and contribute to EC proliferation and/or altered production of endothelium-derived stimulants of PASMC or EC growth. However, $\left[\mathrm{Ca}^{2+}\right]_{\mathrm{i}}$ was reduced in ECs isolated from hypoxic rats [105], perhaps reflecting differences between in vivo and in vitro hypoxic exposure or species.

\section{$\mathrm{Na}^{+} / \mathrm{H}^{+}$Exchange and $\mathrm{pH}$ Homeostasis}

The $\mathrm{Na}^{+} / \mathrm{H}^{+}$exchanger (NHE) is major contributor to maintenance of PASMC $\mathrm{pH}$ homeostasis $[106,107]$. Of particular interest, NHE activity was associated with growth 
factor-induced proliferation [108] and follow-up reports demonstrated increased expression of NHE isoform 1 (NHE1) in PASMCs from $\mathrm{CH}$ animals, leading to increased NHE activity and alkaline $\mathrm{pH}[109,110]$. Reducing NHE activity, by pharmacological inhibition [111] or genetic deletion of NHE1 [112, 113], decreased hypoxia-induced vascular remodeling and PASMC proliferation and migration [113]. Hypoxia also increased NHE1 expression in ECs [114], but whether NHE1 contributes to hypoxia-induced EC migration and tube formation [115], or angiogenesis in chronically hypoxic rats [10, 35], is unknown.

The exact mechanism by which NHE1 controls migration and proliferation is unclear, although recent studies have provided tantalizing clues. In PASMCs, loss of NHE1 increased p27, a cyclin-dependent kinase inhibitor, and decreased E2F1, a nuclear transcription factor that controls proliferation [113], suggesting that NHE1 activation represses a growth inhibitor pathway while stimulating proliferation. In fibroblasts, NHE1 binds to actin filaments through the adaptor protein, ezrin, providing a link between NHE1 and cytoskeletal re-arrangement [116]. Preliminary studies indicate similar NHE1-actin interactions occur in PASMCs [117].

Selective inhibitors of NHE1 were developed for treatment of myocardial infarction; however, major side effects, including cerebrovascular events [118], coupled with limited beneficial effect led to withdrawal of these drugs from clinical use [119]. Given the wide distribution of NHE1 throughout the body, NHE inhibitors may only be useful in the treatment of PAH if cell-specific targeting could be achieved.

\section{Rho Kinase and Remodeling}

While the Rho kinase (ROCK) signaling pathway plays a central role in mediating vasoconstriction in all PH models [120, 121], ROCK activation is also implicated in the remodeling process $[122,123]$. ROCK activation is necessary for migration and proliferation in a variety of vascular cell types, including PASMCs [123-126]. RhoA and RhoB, upstream activators of ROCK, mediate cytoskeletal re-arrangement in PASMCs and ECs, with RhoB contributing to hypoxia-induced migration and proliferation in both cell types [100]. Convergence with other mechanisms involved in remodeling appears certain, as ROCK activation is a consequence of several growth factors, opens $\mathrm{Ca}^{2+}$ channels [85, 90], and stimulates the activity of [127] and is activated by [112] NHE1.

Acute intravenous administration of ROCK inhibitors reduced $\mathrm{P}_{\mathrm{pa}}$ and PVR in PH models and PAH patients [128, 129]; however, substantial systemic hypotension with intravenous delivery limits their use. Inhaled ROCK inhibitors circumvent negative systemic side effects [130], and acutely reduced PVR in PAH patients [131]. Chronic treatment with ROCK inhibitors reduced neovascularization and remodeling in PH models [10, 132, 133] suggesting that prolonged use could be effective in slowing and/or reversing remodeling in the patient population. Indeed, both sildenfil and statins can inhibit ROCK [97, 134], although the extent to which the clinical dosing of these drugs inhibits ROCK activation and influences remodeling in patients is unclear.

\section{BMP signaling}

BMP binding to complexes containing type I and type II receptors results in signaling through SMAD-dependent and -independent pathways [55]. In general, BMP/type I receptor interactions activate SMAD1/5/8, increasing binding with SMAD4, nuclear translocation and activation of transcriptional responses [54]. SMAD-independent signaling involves MAP kinases (MAPKs), phosphatidylinositol 3-kinase/AKT and protein kinase C [124]. BMP receptor binding and activity in vivo is also regulated by a variety of endogenous antagonists and binding proteins $[54,55]$. 
Most work examining the role of BMPs in pulmonary vascular remodeling has focused on the ligands BMP2, -4 , and -7 and the receptors, BMPR1 and BMPR2. Early on, BMPs were recognized to exert differential effects on PASMCs depending on the location within the vasculature. For example, BMP2 and BMP4 were anti-proliferative in PASMCs from proximal vesssels [135], but BMP4 increased $\left[\mathrm{Ca}^{2+}\right]_{\mathrm{i}}$ via TRPC upregulation [136] and induced proliferation [137] in PASMCs from distal vessels. The differential roles of BMPs were further highlighted in mice with partial deficiency for BMP2 and BMP4, which were found to be more susceptible to and protected against development of $\mathrm{PH}$, respectively [62, $138,139]$.

In PASMCs from PAH patients, BMPR2 mutations reduce BMP signaling, leading to loss of the antiproliferative effects of BMP2 [59]. BMPR1 and BMPR2 expression is also decreased in non-PAH forms of the disease [140] and in $\mathrm{CH}$ models [141], suggesting dysregulation of BMP signaling may be a common feature of PH. In ECs, loss of BMPR2 results in apoptosis [142], a likely early event in the pathogenesis of PAH. Moreover, activation of endothelial BMPR2 by BMP2 or BMP4 was linked to nitric oxide production [143], providing a paracrine effect whereby normal BMP signaling exerts antiproliferative effects on PASMCs. Sildenafil restored BMP signaling in PAH PASMCs [96], whereas simvastatin increased BMPR2 expression in ECs [144], suggesting these drugs might rescue BMP function in vivo. Identifying other means of increasing BMPR2 expression/activity during PH remains an area of active investigation.

\section{Endothelin-1}

In 1988, a peptide secreted by ECs was sequenced, characterized as a potent vasoconstrictor and named endothelin [145]. Although three isoforms of endothelin have been identified, endothelin-1 (ET-1) is the most widely expressed, and thus, most studied. In addition to vasoconstriction, ET-1 induces migration and proliferation of vascular cells [146]. In PASMCs, ET-1 binds to two membrane bound receptors $\left(\mathrm{ET}_{\mathrm{A}}\right.$ and $\left.\mathrm{ET}_{\mathrm{B}}\right)$, resulting in a complicated signaling pathway [147], involving inhibition of $\mathrm{K}^{+}$channel expression and activity, increased $\left[\mathrm{Ca}^{2+}\right]_{\mathrm{i}}$ and activation of NHE1 and ROCK [127, 147, 148]. PASMCs express both $\mathrm{ET}_{\mathrm{A}}$ and $\mathrm{ET}_{\mathrm{B}}$ receptors which mediate contraction, proliferation and migration, whereas ECs express only $\mathrm{ET}_{\mathrm{B}}$ receptors which are thought to act as a "sink" for circulating ET-1 and lead to production of NO. However, since the majority of ET-1 is secreted basolaterally, PASMCs are likely to be the main target of ET-1 binding.

Circulating ET-1 levels are increased in all animal models and human forms of PH [146, 147]. ET receptor inhibitors prevented and reversed $\mathrm{PH}$ and vascular remodeling in several animal models [149], positive results that led to introduction of ET receptor inhibitors into clinical practice. ET receptor inhibitors improve exercise capacity and survival [149], but whether this is due to reduced vasoconstriction or remodeling, or other effects of the drugs, is unclear.

\section{Serotonin}

As mentioned earlier in this review, 5-HT uptake can influence PASMC growth and vascular remodeling. The 5-HT signaling cascade involves generation of reactive oxygen species, activation of MAPKs and ROCK, and induction of genes involved in regulating cell growth [50]. Some of these responses can be attributed to internalization and receptorindependent signaling [50]. Coordination between SERT and 5-HT receptor binding may also occur, since inhibiting 5- $\mathrm{HT}_{1 \mathrm{~B}}$ receptors by silencing or pharmacological inhibitors reduced PASMC proliferation and $\mathrm{CH}$-induced remodeling [50], responses mediated by SERT [51,52]. While increasing 5-HT internalization via SERT over-expression is 
sufficient to induce ROCK-dependent remodeling in mice [150], studies infusing 5-HT into BMPR2 heterozygotes indicate elevated 5-HT levels can also act as a second hit [50].

\section{Hypoxia-inducible factors}

The discovery of the heterodimeric oxygen-sensitive transcription factor, hypoxia-inducible factor 1 (HIF-1) [151] provided an attractive new candidate for mediating hypoxia-induced $\mathrm{PH}$. The $\beta$ subunit of HIF-1 (HIF-1 $\beta$;) is constitutively expressed whereas the a subunit (HIF-1a) is typically not detectable under normoxic conditions. The mystery of how HIF-1 responded to changes in oxygen was unraveled in 2001, when it was reported that HIF-1a is hydroxylated on two proline residues, using molecular oxygen as a substrate, allowing binding to the von Hippel-Lindau protein, ubiquitination and targeting for proteasomal degradation (reviewed in [152] and [153]). As oxygen levels fall, hydroxylation becomes limited and HIF-1a accumulates. HIF-1 transactivation is further regulated by asparagine hydroxylation of HIF-1a. Thus, HIF-1a hydroxylation controls activation of the HIF-1 transcription complex. Subsequent studies identified HIF-2 $a$ as an additional binding partner for HIF-1 $\beta$, resulting in the HIF-2 transcription factor [153]. Unlike HIF-1a, which is found in all cells, HIF-2a exhibits a more restricted expression pattern.

Animal studies revealed a role for HIF-1 in the development of hypoxia-induced PH [154156]. Generation of mice homozygous for a null HIF-1a allele resulted in embryonic lethality [157]. In contrast, mice heterozygous for the null allele $\left(\mathrm{Hifl}^{+/-}\right)$were viable with phenotypically normal appearance under normoxic conditions but exhibited impaired development of PH and reduced remodeling in response to $\mathrm{CH}$ [154]. PASMCs from $\mathrm{Hifla}^{+/-}$mice also exhibited reduced hypoxia-induced proliferation [156]. Similar attenuation in $\mathrm{CH}$-induced remodeling was observed in $\mathrm{Hif}_{2} \mathrm{a}^{+/-}$mice [158].

The exact mechanisms by which HIF-1 mediates remodeling during $\mathrm{CH}$ are still being investigated (Fig. 2), but are likely to involve both $\mathrm{Ca}^{2+}$ and $\mathrm{pH}$ homeostasis $[155,156$, 159]. HIF also regulates other factors involved in the pathogenesis of PH, including ET-1 and VEGF [153]. Recent studies targeting HIF activity using pharmacologic inhibitors showed reduced $\mathrm{CH}$-induced vascular remodeling in rodents [160], providing an attractive therapeutic potential for drugs that block or reduce HIF. Fawn-hooded rats also exhibit upregulation of HIF-1, even under normoxic conditions 69 , which is hypothesized to be due to mitochondrial dysfunction. Moreover, accumulation of HIF-1a protein was observed in the lungs of PAH patients. While reduced oxygen is an obvious stimulant for HIF-1a accumulation, whether increased HIF-1a levels in PAH patients reflect local areas of hypoxia remains uncertain. Alternatively, other factors have been shown to induce normoxic accumulation of HIF-1 $[152,153]$ and may play a role in activating HIF signaling pathways in PAH.

\section{Concluding Remarks}

$\mathrm{PH}$, regardless of inciting cause, is a complex disorder in humans. Preclinical models have aided in understanding the remodeling that occurs, identifying cellular mechanisms involved, and investigating potential therapies. While progress has been made, none of the preclinical models fully recapitulates the human disorder, and much is yet to be learned regarding the mechanisms controlling PASMC and EC proliferation, migration, hypertrophy and apoptosis. Since none of the currently available treatments for PAH are curative and are often accompanied by negative side-effects or inconvenient routes of administration, the search for novel therapeutic targets is imperative. While several promising potential therapies have emerged from the study of animal models, including dichloroacetate, as well as ROCK, NFAT and HIF inhibitors, clinical trials will need to be performed to assess the extent of their benefit in the patient population. Further investigation is clearly warranted to 
identify additional mechanisms involved in the pathogenesis of vascular remodeling and develop new pharmacological agents aimed at targeting and reversing the remodeling process.

\section{Acknowledgments}

The authors are supported by grants from the National Institutes of Health (HL073589, HL096982, HL114902 and HL67191).

\section{References}

1. Galie N, Hoeper MM, Humbert M, Torbicki A, Vachiery JL, Barbera JA, Beghetti M, Corris P, Gaine S, Gibbs JS, et al. Guidelines for the diagnosis and treatment of pulmonary hypertension: the Task Force for the Diagnosis and Treatment of Pulmonary Hypertension of the European Society of Cardiology (ESC) and the European Respiratory Society (ERS), endorsed by the International Society of Heart and Lung Transplantation (ISHLT). Eur Heart J. 2009; 30:2493-2537. [PubMed: 19713419]

2. Badesch DB, Champion HC, Sanchez MA, Hoeper MM, Loyd JE, Manes A, McGoon M, Naeije R, Olschewski H, Oudiz RJ, et al. Diagnosis and assessment of pulmonary arterial hypertension. J Am Coll Cardiol. 2009; 54:S55-66. [PubMed: 19555859]

3. Voelkel NF, Tuder RM. Hypoxia-induced pulmonary vascular remodeling: a model for what human disease? J Clin Invest. 2000; 106:733-738. [PubMed: 10995781]

4. Stenmark KR, Meyrick B, Galie N, Mooi WJ, McMurtry IF. Animal models of pulmonary arterial hypertension: the hope for etiological discovery and pharmacological cure. Am J Physiol Lung Cell Mol Physiol. 2009; 297:L1013-1032. [PubMed: 19748998]

5. Tuder RM. Pathology of pulmonary arterial hypertension. Semin Respir Crit Care Med. 2009; 30:376-385. [PubMed: 19634077]

6. Stenmark KR, Rabinovitch M. Emerging therapies for the treatment of pulmonary hypertension. Pediatr Crit Care Med. 2010; 11:S85-90. [PubMed: 20216170]

7. Gan CT-J, Lankhaar J-W, Westerhof N, Marcus JT, Becker A, Twisk JWR, Boonstra A, Postmus PE, Vonk-Noordegraaf A. Noninvasively assessed pulmonary artery stiffness predicts mortality in pulmonary arterial hypertension. Chest. 2007; 132(6):1906-12. [PubMed: 17989161]

8. Mahapatra S, Nishimura RA, Sorajja P, Cha S, McGoon MD. Relationship of pulmonary arterial capacitance and mortality in idiopathic pulmonary arterial hypertension. J Am Coll Cardiol. 2006; 47:799-803. [PubMed: 16487848]

9. Vanderpool RR, Kim AR, Molthen R, Chesler NC. Effects of acute Rho kinase inhibition on chronic hypoxia-induced changes in proximal and distal pulmonary arterial structure and function. $\mathrm{J}$ Appl Physiol. 2011; 110:188-198. [PubMed: 21088209]

10. Hyvelin J-M, Howell K, Nichol A, Costello CM, Preston RJ, McLoughlin P. Inhibition of Rhokinase attenuates hypoxia-induced angiogenesis in the pulmonary circulation. Circ Res. 2005; 97:185-191. [PubMed: 15961717]

11. Stenmark KR, McMurtry IF. Vascular remodeling versus vasoconstriction in chronic hypoxic pulmonary hypertension: a time for reappraisal? Circ Res. 2005; 97:95-98. [PubMed: 16037575]

12. McMurtry IV, Abe K, Ota H, Fagan KA, Oka M. Rho kinase-mediated vasoconstriction in pulmonary hypertension. Adv Exp Med Biol. 2010; 661:299-308. [PubMed: 20204738]

13. Penaloza D, Arias-Stella J, Sime F, Recavarren S, Marticorena E. The heart and pulmonary circulation in children at high altitudes: physiological, anatomical, and clinical observations. Pediatrics. 1964; 34:568-582. [PubMed: 14212475]

14. Rotta A, Canepa A, Hurtado A, Velasquez T, Chavez R. Pulmonary circulation at sea level and at high altitudes. J Appl Physiol. 1956; 9:328-336. [PubMed: 13376451]

15. Pryor R, Weaver WF, Blount SG. Electrocardiographic observation of 493 residents living at high altitude (10,150 feet). Am J Cardiol. 1965; 16:494-499. [PubMed: 5834470]

16. Naeye RL. Hypoxemia and pulmonary hypertension. A study of the pulmonary vasculature. Arch Pathol. 1961; 71:447-452. [PubMed: 13727385] 
17. Naeye RL. Children at high altitude: pulmonary and renal abnormalities. Circ Res. 1965; 16:3338. [PubMed: 14252154]

18. Arias-Stella J, Saldana M. The terminal portion of the pulmonary arterial tree in people native to high altitudes. Circulation. 1963; 28:915-925. [PubMed: 14079195]

19. Heath D, Smith P, Rios Dalenz J, Williams D, Harris P. Small pulmonary arteries in some natives of La Paz, Bolivia. Thorax. 1981; 36:599-604. [PubMed: 7314035]

20. Groves BM, Droma T, Sutton JR, McCullough RG, McCullough RE, Zhuang J, Rapmund G, Sun $\mathrm{S}$, Janes C, Moore LG. Minimal hypoxic pulmonary hypertension in normal Tibetans at 3,658 m. J Appl Physiol. 1993; 74:312-318. [PubMed: 8444708]

21. Gupta ML, Rao KS, Anand IS, Banerjee AK, Boparai MS. Lack of smooth muscle in the small pulmonary arteries of the native Ladakhi. Is the Himalayan highlander adapted? Am Rev Respir Dis. 1992; 145:1201-4. [PubMed: 1586066]

22. Wilkinson M, Langhorne CA, Heath D, Barer GR, Howard P. A pathophysiological study of 10 cases of hypoxic cor pulmonale. Q J Med. 1988; 66:65-85. [PubMed: 3174923]

23. Barberà JA, Riverola A, Roca J, Ramirez J, Wagner PD, Ros D, Wiggs BR, Rodriguez-Roisin R. Pulmonary vascular abnormalities and ventilation-perfusion relationships in mild chronic obstructive pulmonary disease. Am J Respir Crit Care Med. 1994; 149:423-429. [PubMed: 8306040]

24. Wright JL, Petty T, Thurlbeck WM. Analysis of the structure of the muscular pulmonary arteries in patients with pulmonary hypertension and COPD: National Institutes of Health nocturnal oxygen therapy trial. Lung. 1992; 170:109-124. [PubMed: 1501507]

25. Santos S, Peinado VI, Ramírez J, Melgosa T, Roca J, Rodriguez-Roisin R, Barberà JA. Characterization of pulmonary vascular remodelling in smokers and patients with mild COPD. Eur Respir J. 2002; 19:632-638. [PubMed: 11998991]

26. Voelkel N, Mizuno S, Gomez-Arroyo J. COPD/emphysema: The vascular story. Pulm Circ. 2011; 3:320. [PubMed: 22140621]

27. Glover GH, Newsom IE. Brisket disease: dropsy of high altitudes. Colo Agric Exp Station. 1915; 204:3-24.

28. Rhodes J. Comparative physiology of hypoxic pulmonary hypertension: historical clues from brisket disease. J Appl Physiol. 2005; 98:1092-1100. [PubMed: 15703167]

29. Stenmark KR, Fasules J, Hyde DM, Voelkel NF, Henson J, Tucker A, Wilson H, Reeves JT. Severe pulmonary hypertension and arterial adventitial changes in newborn calves at 4,300 m. J Appl Physiol. 1987; 62:821-830. [PubMed: 3558241]

30. Rabinovitch M, Gamble WJ, Nadas AS, Miettinen OS, Reid L. Rat pulmonary circulation after chronic hypoxia: hemodynamic and structural features. Am J Physiol. 1979; 236:H818-827. [PubMed: 443445]

31. Rabinovitch M, Chesler N, Molthen RC. Point:Counterpoint: Chronic hypoxia-induced pulmonary hypertension does/does not lead to loss of pulmonary vasculature. J Appl Physiol. 2007; 103:1449-1451. [PubMed: 17363624]

32. Hislop A, Reid L. New findings in pulmonary arteries of rats with hypoxia-induced pulmonary hypertension. Br J Exp Pathol. 1976; 57:542-554. [PubMed: 136978]

33. Berg JT. Chronic hypoxia-induced pulmonary hypertension does/does not lead to loss of pulmonary vasculature. J Appl Physiol. 2007; 103:1455. [PubMed: 17916681]

34. Mcloughlin P, Mcmurtry I. Counterpoint: Chronic hypoxia-induced pulmonary hypertension does not lead to loss of pulmonary vasculature. J Appl Physiol. 2007; 103:1451-1453. discussion 14531454. [PubMed: 17916678]

35. Howell K, Preston RJ, McLoughlin P. Chronic hypoxia causes angiogenesis in addition to remodelling in the adult rat pulmonary circulation. J Physiol. 2003; 547:133-145. [PubMed: 12562951]

36. Bauer NR, Moore TM, McMurtry IF. Rodent models of PAH: are we there yet? Am J Physiol Lung Cell Mol Physiol. 2007; 293:L580-582. [PubMed: 17660327]

37. Paddenberg R, Stieger P, Von Lilien A-L, Faulhammer P, Goldenberg A, Tillmanns HH, Kummer W, Braun-Dullaeus RC. Rapamycin attenuates hypoxia-induced pulmonary vascular remodeling and right ventricular hypertrophy in mice. Respir Res. 2007; 8:15. [PubMed: 17319968] 
38. Stenmark KR, Fagan KA, Frid MG. Hypoxia-induced pulmonary vascular remodeling: cellular and molecular mechanisms. Circ Res. 2006; 99:675-691. [PubMed: 17008597]

39. Jaenke RS, Alexander AF. Fine structural alterations of bovine peripheral pulmonary arteries in hypoxia-induced hypertension. Am J Pathol. 1973; 73:377-398. [PubMed: 4357176]

40. Nagaoka T, Muramatsu M, Sato K, McMurtry I, Oka M, Fukuchi Y. Mild hypoxia causes severe pulmonary hypertension in fawn-hooded but not in Tester Moriyama rats. Respir Physiol. 2001; 127:53-60. [PubMed: 11445200]

41. Sato K, Webb S, Tucker A, Rabinovitch M, O’Brien RF, McMurtry IF, Stelzner TJ. Factors influencing the idiopathic development of pulmonary hypertension in the fawn hooded rat. Am Rev Respir Dis. 1992; 145:793-797. [PubMed: 1554204]

42. Taraseviciene-Stewart L, Kasahara Y, Alger L, Hirth P, Mc Mahon G, Waltenberger J, Voelkel NF, Tuder RM. Inhibition of the VEGF receptor 2 combined with chronic hypoxia causes cell death-dependent pulmonary endothelial cell proliferation and severe pulmonary hypertension. FASEB J. 2001; 15:427-438. [PubMed: 11156958]

43. Abe K, Toba M, Alzoubi A, Ito M, Fagan KA, Cool CD, Voelkel NF, McMurtry IF, Oka M. Formation of plexiform lesions in experimental severe pulmonary arterial hypertension. Circulation. 2010; 121:2747-2754. [PubMed: 20547927]

44. Ciuclan L, Bonneau O, Hussey M, Duggan N, Holmes AM, Good R, Stringer R, Jones P, Morrell NW, Jarai G, et al. A novel murine model of severe pulmonary arterial hypertension. Am J Respir Crit Care Med. 2012; 184:1171-1182. [PubMed: 21868504]

45. Kay JM, Harris P, Heath D. Pulmonary hypertension produced in rats by ingestion of Crotalaria spectabilis seeds. Thorax. 1967; 22:176-179. [PubMed: 6033385]

46. Gomez-Arroyo J, Saleem SJ, Mizuno S, Syed AA, Bogaard HJ, Abbate A, Taraseviciene-Stewart L, Sung Y, Kraskauskas D, Farkas D, et al. A brief overview of mouse models of pulmonary arterial hypertension: problems and prospects. Am J Physiol Lung Cell Mol Physiol. 2012; 302:L977-991. [PubMed: 22307907]

47. Meyrick B, Gamble W, Reid L. Development of Crotalaria pulmonary hypertension: hemodynamic and structural study. Am J Physiol. 1980; 239:H692-702. [PubMed: 6449154]

48. Tanaka Y, Schuster DP, Davis EC, Patterson GA, Botney MD. The role of vascular injury and hemodynamics in rat pulmonary artery remodeling. J Clin Invest. 1996; 98:434-42. [PubMed: 8755654]

49. Okada K, Tanaka Y, Bernstein M, Zhang W, Patterson GA, Botney MD. Pulmonary hemodynamics modify the rat pulmonary artery response to injury. A neointimal model of pulmonary hypertension. Am J Pathol. 1997; 151:1019-1025. [PubMed: 9327735]

50. Maclean MR, Dempsie Y. The serotonin hypothesis of pulmonary hypertension revisited. Adv Exp Med Biol. 2010; 661:309-322. [PubMed: 20204739]

51. MacLean MR, Alexander D, Stirrat A, Gallagher M, Douglas SA, Ohlstein EH, Morecroft I, Polland K. Contractile responses to human urotensin-II in rat and human pulmonary arteries: effect of endothelial factors and chronic hypoxia in the rat. Br J Pharmacol. 2000; 130:201-204. [PubMed: 10807654]

52. Eddahibi S, Fabre V, Boni C, Martres MP, Raffestin B, Hamon M, Adnot S. Induction of serotonin transporter by hypoxia in pulmonary vascular smooth muscle cells. Relationship with the mitogenic action of serotonin. Circ Res. 1999; 84:329-36. [PubMed: 10024307]

53. White K, Dempsie Y, Nilsen M, Wright AF, Loughlin L, MacLean MR. The serotonin transporter, gender, and $17 \beta$ oestradiol in the development of pulmonary arterial hypertension. Cardiovasc Res. 2011; 90:373-382. [PubMed: 21177701]

54. Lowery JW, de Caestecker MP. BMP signaling in vascular development and disease. Cytokine Growth Factor Rev. 2010; 21:287-298. [PubMed: 20674464]

55. Sieber C, Kopf J, Hiepen C, Knaus P. Recent advances in BMP receptor signaling. Cytokine Growth Factor Rev. 2009; 20:343-355. [PubMed: 19897402]

56. Deng Z, Morse JH, Slager SL, Cuervo N, Moore KJ, Venetos G, Kalachikov S, Cayanis E, Fischer SG, Barst RJ, et al. Familial primary pulmonary hypertension (gene PPH1) is caused by mutations in the bone morphogenetic protein receptor-II gene. Am J Hum Genet. 2000; 67:737-44.

[PubMed: 10903931] 
57. Elliott CG. Genetics of pulmonary arterial hypertension: current and future implications. Semin Respir Crit Care Med. 2005; 26:365-71. [PubMed: 16121312]

58. Newman JH, Phillips JA, Loyd JE. Narrative review: the enigma of pulmonary arterial hypertension: new insights from genetic studies. Ann Intern Med. 2008; 148:278-283. [PubMed: 18283205]

59. Davies RJ, Morrell NW. Molecular mechanisms of pulmonary arterial hypertension: role of mutations in the bone morphogenetic protein type II receptor. Chest. 2008; 134:1271-1277. [PubMed: 19059957]

60. Beppu H, Ichinose F, Kawai N, Jones RC, Yu PB, Zapol WM, Miyazono K, Li E, Bloch KD. BMPR-II heterozygous mice have mild pulmonary hypertension and an impaired pulmonary vascular remodeling response to prolonged hypoxia. Am J Physiol Lung Cell Mol Physiol. 2004; 287:L1241-7. [PubMed: 15286002]

61. Song Y, Jones JE, Beppu H, Keaney JF, Loscalzo J, Zhang Y-Y. Increased susceptibility to pulmonary hypertension in heterozygous BMPR2-mutant mice. Circulation. 2005; 112:553-562. [PubMed: 16027259]

62. Frank DB, Lowery J, Anderson L, Brink M, Reese J, de Caestecker M. Increased susceptibility to hypoxic pulmonary hypertension in Bmpr2 mutant mice is associated with endothelial dysfunction in the pulmonary vasculature. Am J Physiol Lung Cell Mol Physiol. 2008; 294:L98-109. [PubMed: 18024717]

63. West J, Fagan K, Steudel W, Fouty B, Lane K, Harral J, Hoedt-Miller M, Tada Y, Ozimek J, Tuder $\mathrm{R}$, et al. Pulmonary hypertension in transgenic mice expressing a dominant-negative BMPRII gene in smooth muscle. Circ Res. 2004; 94:1109-1114. [PubMed: 15031260]

64. Suzuki H, Twarog BM. Membrane properties of smooth muscle cells in pulmonary hypertensive rats. Am J Physiol. 1982; 242:H907-915. [PubMed: 6805338]

65. Shimoda LA, Polak J. Theme: Hypoxia Hypoxia and ion channel function. Am J Physiol Cell Physiol. 2011; 300(5):C951-67. [PubMed: 21178108]

66. Yuan JX, Aldinger AM, Juhaszova M, Wang J, Conte JV Jr, Gaine SP, Orens JB, Rubin LJ. Dysfunctional voltage-gated $\mathrm{K}^{+}$channels in pulmonary artery smooth muscle cells of patients with primary pulmonary hypertension. Circulation. 1998; 98:1400-1406. [PubMed: 9760294]

67. Burg ED, Remillard CV, Yuan JX. Potassium channels in the regulation of pulmonary artery smooth muscle cell proliferation and apoptosis: pharmacotherapeutic implications. Br J Pharmacol. 2008; 153(Suppl 1):S99-S111. [PubMed: 18084317]

68. Michelakis ED, McMurtry MS, Wu XC, Dyck JR, Moudgil R, Hopkins TA, Lopaschuk GD, Puttagunta L, Waite R, Archer SL. Dichloroacetate, a metabolic modulator, prevents and reverses chronic hypoxic pulmonary hypertension in rats: role of increased expression and activity of voltage-gated potassium channels. Circulation. 2002; 105:244-250. [PubMed: 11790708]

69. Bonnet S, Michelakis ED, Porter CJ, Andrade-Navarro MA, Thebaud B, Bonnet S, Haromy A, Harry G, Moudgil R, McMurtry MS, et al. An abnormal mitochondrial-hypoxia inducible factor-1a-Kv channel pathway disrupts oxygen sensing and triggers pulmonary arterial hypertension in fawn hooded rats: similarities to human pulmonary arterial hypertension. Circulation. 2006; 113:2630-2641. [PubMed: 16735674]

70. Yuan XJ, Wang J, Juhaszova M, Gaine SP, Rubin LJ. Attenuated $\mathrm{K}^{+}$channel gene transcription in primary pulmonary hypertension. Lancet. 1998; 351:726-727. [PubMed: 9504523]

71. Bonnet S, Rochefort G, Sutendra G, Archer SL, Haromy A, Webster L, Hashimoto K, Bonnet SN, Michelakis ED. The nuclear factor of activated T cells in pulmonary arterial hypertension can be therapeutically targeted. Proc Natl Acad Sci U S A. 2007; 104:11418-11423. [PubMed: 17596340]

72. Pozeg ZI, Michelakis ED, McMurtry MS, Thebaud B, Wu XC, Dyck JR, Hashimoto K, Wang S, Moudgil R, Harry G, et al. In vivo gene transfer of the $\mathrm{O}_{2}$-sensitive potassium channel Kv1.5 reduces pulmonary hypertension and restores hypoxic pulmonary vasoconstriction in chronically hypoxic rats. Circulation. 2003; 107:2037-2044. [PubMed: 12695303]

73. Shimoda LA, Sham JS, Shimoda TH, Sylvester JT. L-type $\mathrm{Ca}^{2+}$ channels, resting $\left[\mathrm{Ca}^{2+}\right]_{\mathrm{i}}$, and ET-1-induced responses in chronically hypoxic pulmonary myocytes. Am J Physiol Lung Cell Mol Physiol. 2000; 279:L884-894. [PubMed: 11053024] 
74. Wang J, Weigand L, Lu W, Sylvester JT, Semenza GL, Shimoda LA. Hypoxia inducible factor 1 mediates hypoxia-induced TRPC expression and elevated intracellular $\mathrm{Ca}^{2+}$ in pulmonary arterial smooth muscle cells. Circ Res. 2006; 98:1528-1537. [PubMed: 16709899]

75. Lin MJ, Leung GP, Zhang WM, Yang XR, Yip KP, Tse CM, Sham JS. Chronic hypoxia-induced upregulation of store-operated and receptor-operated $\mathrm{Ca}^{2+}$ channels in pulmonary arterial smooth muscle cells: a novel mechanism of hypoxic pulmonary hypertension. Circ Res. 2004; 95:496505. [PubMed: 15256480]

76. Rich S, Kaufmann E, Levy PS. The effect of high doses of calcium-channel blockers on survival in primary pulmonary hypertension. N Engl J Med. 1992; 327:76-81. [PubMed: 1603139]

77. Sitbon O, Humbert M, Jais X, Ioos V, Hamid AM, Provencher S, Garcia G, Parent F, Herve P, Simonneau G. Long-term response to calcium channel blockers in idiopathic pulmonary arterial hypertension. Circulation. 2005; 111:3105-3111. [PubMed: 15939821]

78. Bonnet S, Dumas-de-La-Roque E, Begueret H, Marthan R, Fayon M, Dos Santos P, Savineau JP, Baulieu EE. Dehydroepiandrosterone (DHEA) prevents and reverses chronic hypoxic pulmonary hypertension. Proc Natl Acad Sci U S A. 2003; 100:9488-9493. [PubMed: 12878719]

79. McMurtry MS, Bonnet S, Wu X, Dyck JR, Haromy A, Hashimoto K, Michelakis ED. Dichloroacetate prevents and reverses pulmonary hypertension by inducing pulmonary artery smooth muscle cell apoptosis. Circ Res. 2004; 95:830-840. [PubMed: 15375007]

80. Golovina VA, Platoshyn O, Bailey CL, Wang J, Limsuwan A, Sweeney M, Rubin LJ, Yuan JX. Upregulated TRP and enhanced capacitative $\mathrm{Ca}^{2+}$ entry in human pulmonary artery myocytes during proliferation. Am J Physiol Heart Circ Physiol. 2001; 280:H746-755. [PubMed: 11158974]

81. Landsberg JW, Yuan JX. Calcium and TRP channels in pulmonary vascular smooth muscle cell proliferation. News Physiol Sci. 2004; 19:44-50. [PubMed: 15016901]

82. Leggett K, Maylor J, Undem C, Lai N, Lu W, Schweitzer KS, King LS, Myers AC, Sylvester JT, Sidhaye VK, et al. Hypoxia-induced migration in pulmonary arterial smooth muscle cells requires calcium-dependent upregulation of aquaporin 1. Am J Physiol Lung Cell Mol Physiol. 2012; 303:L343-353. [PubMed: 22683574]

83. Liu XR, Zhang MF, Yang N, Liu Q, Wang RX, Cao YN, Yang XR, Sham JS, Lin MJ. Enhanced store-operated $\mathrm{Ca}^{2+}$ entry and TRPC channel expression in pulmonary arteries of monocrotalineinduced pulmonary hypertensive rats. Am J Physiol Cell Physiol. 2012; 302:C77-87. [PubMed: 21940663]

84. Song MY, Makino A, Yuan JX. STIM2 contributes to enhanced store-operated Ca entry in pulmonary artery smooth muscle cells from patients with idiopathic pulmonary arterial hypertension. Pulm Circ. 2011; 1:84-94. [PubMed: 21709766]

85. Luke T, Maylor J, Undem C, Sylvester JT, Shimoda LA. Kinase dependent activation of voltagegated $\mathrm{Ca}^{2+}$ channels by ET-1 in pulmonary arterial myocytes during chronic hypoxia. Am J Physiol Lung Cell Mol Physiol. 2012; 302:L1128-1139. [PubMed: 22387294]

86. Hirenallur SD, Haworth ST, Leming JT, Chang J, Hernandez G, Gordon JB, Rusch NJ. Upregulation of vascular calcium channels in neonatal piglets with hypoxia-induced pulmonary hypertension. Am J Physiol Lung Cell Mol Physiol. 2008; 295:L915-924. [PubMed: 18776054]

87. Rodman DM, Reese K, Harral J, Fouty B, Wu S, West J, Hoedt-Miller M, Tada Y, Li KX, Cool C, et al. Low-voltage-activated (T-type) calcium channels control proliferation of human pulmonary artery myocytes. Circ Res. 2005; 96:864-872. [PubMed: 15774856]

88. Hisatsune C, Kuroda Y, Nakamura K, Inoue T, Nakamura T, Michikawa T, Mizutani A, Mikoshiba K. Regulation of TRPC6 channel activity by tyrosine phosphorylation. J Biol Chem. 2004; 279:18887-18894. [PubMed: 14761972]

89. Odell AF, Scott JL, Van Helden DF. EGF induces tyrosine phosphorylation, membrane insertion and activation of transient receptor potential channel 4. J Biol Chem. 2005; 280:37974-37987. [PubMed: 16144838]

90. Wang J, Weigand L, Foxson J, Shimoda LA, Sylvester JT. $\mathrm{Ca}^{2+}$ signaling in hypoxic pulmonary vasoconstriction: effects of myosin light chain and Rho kinase antagonists. Am J Physiol Lung Cell Mol Physiol. 2007; 293:L674-685. [PubMed: 17575009]

91. Yu Y, Fantozzi I, Remillard CV, Landsberg JW, Kunichika N, Platoshyn O, Tigno DD, Thistlethwaite PA, Rubin LJ, Yuan JX. Enhanced expression of transient receptor potential 
channels in idiopathic pulmonary arterial hypertension. Proc Natl Acad Sci U S A. 2004; 101:13861-13866. [PubMed: 15358862]

92. Kunichika N, Landsberg JW, Yu Y, Kunichika H, Thistlethwaite PA, Rubin LJ, Yuan JX. Bosentan inhibits transient receptor potential channel expression in pulmonary vascular myocytes. Am J Respir Crit Care Med. 2004; 170:1101-1107. [PubMed: 15317671]

93. Yu Y, Keller SH, Remillard CV, Safrina O, Nicholson A, Zhang SL, Jiang W, Vangala N, Landsberg JW, Wang JY, et al. A functional single-nucleotide polymorphism in the TRPC6 gene promoter associated with idiopathic pulmonary arterial hypertension. Circulation. 2009; 119:2313-2322. [PubMed: 19380626]

94. Lu W, Ran P, Zhang D, Peng G, Li B, Zhong N, Wang J. Sildenafil inhibits chronically hypoxic upregulation of canonical transient receptor potential expression in rat pulmonary arterial smooth muscle. Am J Physiol Cell Physiol. 2010; 298:C114-123. [PubMed: 19889962]

95. Wharton J, Strange JW, Moller GM, Growcott EJ, Ren X, Franklyn AP, Phillips SC, Wilkins MR. Antiproliferative effects of phosphodiesterase type 5 inhibition in human pulmonary artery cells. Am J Respir Crit Care Med. 2005; 172:105-113. [PubMed: 15817798]

96. Yang J, Li X, Al-Lamki R, Wu C, Weiss A, Berk J, Schermuly RT, Morrell NW. Sildenafil potentiates bone morphogenetic protein signaling in pulmonary arterial smooth muscle cells and in experimental pulmonary hypertension. Arterioscler Thromb Vasc Biol. 2013; 33:34-42. [PubMed: 23139294]

97. Guilluy C, Sauzeau V, Rolli-Derkinderen M, Guerin P, Sagan C, Pacaud P, Loirand G. Inhibition of RhoA/Rho kinase pathway is involved in the beneficial effect of sildenafil on pulmonary hypertension. Br J Pharmacol. 2005; 146:1010-1018. [PubMed: 16205723]

98. Kuhr FK, Smith KA, Song MY, Levitan I, Yuan JX-J. New mechanisms of pulmonary arterial hypertension: role of $\mathrm{Ca}^{2+}$ signaling. Am J Physiol Heart and Circulatory Physiology. 2012; 302:H1546-H1562.

99. Sarkar J, Gou D, Turaka P, Viktorova E, Ramchandran R, Raj JU. MicroRNA-21 plays a role in hypoxia-mediated pulmonary artery smooth muscle cell proliferation and migration. Am J Physiol Lung Cell Mol Physiol. 2010; 299:L861-871. [PubMed: 20693317]

100. Wojciak-Stothard B, Zhao L, Oliver E, Dubois O, Wu Y, Kardassis D, Vasilaki E, Huang M, Mitchell JA, Harrington LS, et al. Role of RhoB in the regulation of pulmonary endothelial and smooth muscle cell responses to hypoxia. Circ Res. 2012; 110:1423-1434. [PubMed: 22539766]

101. Martin E, Dahan D, Cardouat G, Gillibert-Duplantier J, Marthan R, Savineau JP, Ducret T. Involvement of TRPV1 and TRPV4 channels in migration of rat pulmonary arterial smooth muscle cells. Pflugers Arch. 2012; 464:261-272. [PubMed: 22820913]

102. Saadoun S, Papadopoulos MC, Hara-Chikuma M, Verkman AS. Impairment of angiogenesis and cell migration by targeted aquaporin-1 gene disruption. Nature. 2005; 434:786-792. [PubMed: 15815633]

103. Monzani E, Bazzotti R, Perego C, La Porta CA. AQP1 is not only a water channel: it contributes to cell migration through Lin7/beta-catenin. PLoS One. 2009; 4:e6167. [PubMed: 19584911]

104. Fantozzi I, Zhang S, Platoshyn O, Remillard CV, Cowling RT, Yuan JX. Hypoxia increases AP-1 binding activity by enhancing capacitative $\mathrm{Ca}^{2+}$ entry in human pulmonary artery endothelial cells. Am J Physiol Lung Cell Mol Physiol. 2003; 285:L1233-1245. [PubMed: 12909593]

105. Paffett ML, Naik JS, Resta TC, Walker BR. Reduced store-operated $\mathrm{Ca}^{2+}$ entry in pulmonary endothelial cells from chronically hypoxic rats. Am J Physiol Lung Cell Mol Physiol. 2007; 293:L1135-1142. [PubMed: 17693482]

106. Madden JA, Ray DE, Keller PA, Kleinman JG. Ion exchange activity in pulmonary artery smooth muscle cells: the response to hypoxia. Am J Physiol Lung Cell Mol Physiol. 2001; 280:L264271. [PubMed: 11159005]

107. Quinn DA, Honeyman TW, Joseph PM, Thompson BT, Hales CA, Scheid CR. Contribution of $\mathrm{Na}^{+} / \mathrm{H}^{+}$exchange to $\mathrm{pH}$ regulation in pulmonary artery smooth muscle cells. Am J Respir Cell Mol Biol. 1991; 5:586-591. [PubMed: 1659836]

108. Quinn DA, Dahlberg CG, Bonventre JP, Scheid CR, Honeyman T, Joseph PM, Thompson BT, Hales CA. The role of $\mathrm{Na}^{+} / \mathrm{H}^{+}$exchange and growth factors in pulmonary artery smooth muscle cell proliferation. Am J Respir Cell Mol Biol. 1996; 14:139-145. [PubMed: 8630263] 
109. Rios EJ, Fallon M, Wang J, Shimoda LA. Chronic hypoxia elevates intracellular $\mathrm{pH}$ and activates $\mathrm{Na}^{+} / \mathrm{H}^{+}$exchange in pulmonary arterial smooth muscle cells. Am J Physiol Lung Cell Mol Physiol. 2005; 289(5):L867-874. [PubMed: 15964895]

110. Shimoda LA, Fallon M, Pisarcik S, Wang J, Semenza GL. HIF-1 regulates hypoxic induction of NHE1 expression and alkalinization of intracellular $\mathrm{pH}$ in pulmonary arterial myocytes. Am J Physiol Lung Cell Mol Physiol. 2006; 291:L941-949. [PubMed: 16766575]

111. Quinn DA, Du HK, Thompson BT, Hales CA. Amiloride analogs inhibit chronic hypoxic pulmonary hypertension. Am J Respir Crit Care Med. 1998; 157:1263-1268. [PubMed: 9563749]

112. Yu L, Quinn DA, Garg HG, Hales CA. Deficiency of the NHE1 gene prevents hypoxia-induced pulmonary hypertension and vascular remodeling. Am J Respir Crit Care Med. 2008; 177:12761284. [PubMed: 18310478]

113. Yu L, Hales CA. Silencing of NHE1 attenuates PASMC proliferation, hypertrophy and migration via E2F1. Am J Respir Cell Mol Biol. 2011; 45:923-930. [PubMed: 21454803]

114. Cutaia MV, Parks N, Centracchio J, Rounds S, Yip KP, Sun AM. Effect of hypoxic exposure on $\mathrm{Na}^{+} / \mathrm{H}^{+}$antiport activity, isoform expression, and localization in endothelial cells. Am J Physiol. 1998; 275:L442-451. [PubMed: 9728038]

115. Phillips PG, Birnby LM, Narendran A. Hypoxia induces capillary network formation in cultured bovine pulmonary microvessel endothelial cells. Am J Physiol. 1995; 268:L789-800. [PubMed: 7539223]

116. Denker SP, Huang DC, Orlowski J, Furthmayr H, Barber DL. Direct binding of the Na--H exchanger NHE1 to ERM proteins regulates the cortical cytoskeleton and cell shape independently of $\mathrm{H}^{+}$translocation. Mol Cell. 2000; 6:1425-1436. [PubMed: 11163215]

117. Maylor J, Lu W, Pisarcik S, Walker J, Undem C, Myers A, Shimoda L. Reciprocal regulation of $\mathrm{Na}^{+} / \mathrm{H}^{+}$exchanger isoform 1 and $\mathrm{Na}^{+} / \mathrm{H}^{+}$exchange regulatory factor 1 in hypoxic pulmonary arterial smooth muscle cells. FASEB J. 2010; 24:1023.1024. (abstract). [PubMed: 19940258]

118. Mentzer RM Jr, Bartels C, Bolli R, Boyce S, Buckberg GD, Chaitman B, Haverich A, Knight J, Menasche P, Myers ML, et al. Sodium-hydrogen exchange inhibition by cariporide to reduce the risk of ischemic cardiac events in patients undergoing coronary artery bypass grafting: results of the EXPEDITION study. Ann Thorac Surg. 2008; 85:1261-1270. [PubMed: 18355507]

119. Murphy E, Allen DG. Why did the NHE inhibitor clinical trials fail? J Mol Cell Cardiol. 2009; 46:137-141. [PubMed: 19027021]

120. Oka M, Homma N, Taraseviciene-Stewart L, Morris KG, Kraskauskas D, Burns N, Voelkel NF, McMurtry IF. Rho kinase-mediated vasoconstriction is important in severe occlusive pulmonary arterial hypertension in rats. Circ Res. 2007; 100:923-929. [PubMed: 17332430]

121. Ward JPT, Mcmurtry IF. Mechanisms of hypoxic pulmonary vasoconstriction and their roles in pulmonary hypertension: new findings for an old problem. Current Opinion in Pharmacology. 2009; 9:287-296. [PubMed: 19297247]

122. Firth AL, Choi I-W, Park WS. Animal models of pulmonary hypertension: Rho kinase inhibition. Progress in Biophysics and Molecular Biology. 2012; 109:67-75. [PubMed: 22713173]

123. Oka M, Fagan KA, Jones PL, McMurtry IF. Therapeutic potential of RhoA/Rho kinase inhibitors in pulmonary hypertension. Br J Pharmacol. 2008; 155:444-454. [PubMed: 18536743]

124. Yang X, Lee PJ, Long L, Trembath RC, Morrell NW. BMP4 induces HO-1 via a Smadindependent, p38MAPK-dependent pathway in pulmonary artery myocytes. Am J Respir Cell Mol Biol. 2007; 37:598-605. [PubMed: 17600318]

125. Gerthoffer WT. Mechanisms of vascular smooth muscle cell migration. Circ Res. 2007; 100:607621. [PubMed: 17363707]

126. Liu Y, Suzuki YJ, Day RM, Fanburg BL. Rho kinase-induced nuclear translocation of ERK1/ ERK2 in smooth muscle cell mitogenesis caused by serotonin. Circ Res. 2004; 95:579-586. [PubMed: 15297378]

127. Undem C, Rios EJ, Maylor J, Shimoda LA. Endothelin-1 augments $\mathrm{Na}^{+} / \mathrm{H}^{+}$exchange activity in murine pulmonary arterial smooth muscle cells via Rho kinase. PLoS One. 2012; 7:e46303. [PubMed: 23029469] 
128. Fukumoto Y, Matoba T, Ito A, Tanaka H, Kishi T, Hayashidani S, Abe K, Takeshita A, Shimokawa H. Acute vasodilator effects of a Rho-kinase inhibitor, fasudil, in patients with severe pulmonary hypertension. Heart. 2005; 91:391-392. [PubMed: 15710736]

129. Ishikura K, Yamada N, Ito M, Ota S, Nakamura M, Isaka N, Nakano T. Beneficial acute effects of Rho-kinase inhibitor in patients with pulmonary arterial hypertension. Circ J. 2006; 70:174178. [PubMed: 16434811]

130. Nagaoka T, Fagan KA, Gebb SA, Morris KG, Suzuki T, Shimokawa H, McMurtry IF, Oka M. Inhaled Rho kinase inhibitors are potent and selective vasodilators in rat pulmonary hypertension. Am J Respir Crit Care Med. 2005; 171:494-499. [PubMed: 15563635]

131. Fujita H, Fukumoto Y, Saji K, Sugimura K, Demachi J, Nawata J, Shimokawa H. Acute vasodilator effects of inhaled fasudil, a specific Rho-kinase inhibitor, in patients with pulmonary arterial hypertension. Heart Vessels. 2010; 25:144-149. [PubMed: 20339976]

132. Fagan KA, Oka M, Bauer NR, Gebb SA, Ivy DD, Morris KG, McMurtry IF. Attenuation of acute hypoxic pulmonary vasoconstriction and hypoxic pulmonary hypertension in mice by inhibition of Rho-kinase. Am J Physiol Lung Cell Mol Physiol. 2004; 287:L656-664. [PubMed: 14977625]

133. Abe K, Shimokawa H, Morikawa K, Uwatoku T, Oi K, Matsumoto Y, Hattori T, Nakashima Y, Kaibuchi K, Sueishi K, et al. Long-term treatment with a Rho-kinase inhibitor improves monocrotaline-induced fatal pulmonary hypertension in rats. Circ Res. 2004; 94:385-393. [PubMed: 14670839]

134. Girgis RE, Mozammel S, Champion HC, Li D, Peng X, Shimoda LA, Tuder RM, Johns RA, Hassoun PM. Regression of chronic hypoxic pulmonary hypertension by simvastatin. Am J Physiol Lung Cell Mol Physiol. 2007; 292:L1105-1110. [PubMed: 17277047]

135. Morrell NW, Yang X, Upton PD, Jourdan KB, Morgan N, Sheares KK, Trembath RC. Altered growth responses of pulmonary artery smooth muscle cells from patients with primary pulmonary hypertension to transforming growth factor- $\beta 1$ and bone morphogenetic proteins. Circulation. 2001; 104:790-795. [PubMed: 11502704]

136. Lu W, Ran P, Zhang D, Lai N, Zhong N, Wang J. Bone morphogenetic protein 4 enhances canonical transient receptor potential expression, store-operated $\mathrm{Ca}^{2+}$ entry, and basal $\left[\mathrm{Ca}^{2+}\right]_{\mathrm{i}}$ in rat distal pulmonary arterial smooth muscle cells. Am J Physiol Cell Physiol. 2010; 299:C1370 1378. [PubMed: 20844246]

137. Yang X, Long L, Southwood M, Rudarakanchana N, Upton PD, Jeffery TK, Atkinson C, Chen H, Trembath RC, Morrell NW. Dysfunctional Smad signaling contributes to abnormal smooth muscle cell proliferation in familial pulmonary arterial hypertension. Circ Res. 2005; 96:10531063. [PubMed: 15845886]

138. Anderson L, Lowery JW, Frank DB, Novitskaya T, Jones M, Mortlock DP, Chandler RL, de Caestecker MP. Bmp2 and Bmp4 exert opposing effects in hypoxic pulmonary hypertension. Am J Physiol Regul Integr Comp Physiol. 2010; 298:R833-842. [PubMed: 20042692]

139. Frank DB, Abtahi A, Yamaguchi DJ, Manning S, Shyr Y, Pozzi A, Baldwin HS, Johnson JE, de Caestecker MP. Bone morphogenetic protein 4 promotes pulmonary vascular remodeling in hypoxic pulmonary hypertension. Circ Res. 2005; 97:496-504. [PubMed: 16100039]

140. Du L, Sullivan CC, Chu D, Cho AJ, Kido M, Wolf PL, Yuan JX, Deutsch R, Jamieson SW, Thistlethwaite PA. Signaling molecules in nonfamilial pulmonary hypertension. N Engl J Med. 2003; 348:500-509. [PubMed: 12571257]

141. Takahashi H, Goto N, Kojima Y, Tsuda Y, Morio Y, Muramatsu M, Fukuchi Y. Downregulation of type II bone morphogenetic protein receptor in hypoxic pulmonary hypertension. Am J Physiol Lung Cell Mol Physiol. 2006; 290:L450-458. [PubMed: 16361357]

142. Teichert-Kuliszewska K, Kutryk MJ, Kuliszewski MA, Karoubi G, Courtman DW, Zucco L, Granton J, Stewart DJ. Bone morphogenetic protein receptor-2 signaling promotes pulmonary arterial endothelial cell survival: implications for loss-of-function mutations in the pathogenesis of pulmonary hypertension. Circ Res. 2006; 98:209-217. [PubMed: 16357305]

143. Gangopahyay A, Oran M, Bauer EM, Wertz JW, Comhair SA, Erzurum SC, Bauer PM. Bone morphogenetic protein receptor II is a novel mediator of endothelial nitric-oxide synthase activation. J Biol Chem. 2011; 286:33134-33140. [PubMed: 21808054] 
144. Hu H, Sung A, Zhao G, Shi L, Qiu D, Nishimura T, Kao PN. Simvastatin enhances bone morphogenetic protein receptor type II expression. Biochem Biophys Res Commun. 2006; 339:59-64. [PubMed: 16297860]

145. Yanagisawa M, Kurihara H, Kimura S, Goto K, Masaki T. A novel peptide vasoconstrictor, endothelin, is produced by vascular endothelium and modulates smooth muscle $\mathrm{Ca}^{2+}$ channels. $\mathrm{J}$ Hypertens Suppl. 1988; 6:S188-191. [PubMed: 2853725]

146. Shao D, Park JE, Wort SJ. The role of endothelin-1 in the pathogenesis of pulmonary arterial hypertension. Pharmacol Res. 2011; 63:504-511. [PubMed: 21419223]

147. Shimoda LA, Sham JS, Liu Q, Sylvester JT. Acute and chronic hypoxic pulmonary vasoconstriction: a central role for endothelin-1? Respir Physiol Neurobiol. 2002; 132:93-106. [PubMed: 12126698]

148. Whitman EM, Pisarcik S, Luke T, Fallon M, Wang J, Sylvester JT, Semenza GL, Shimoda LA. Endothelin-1 mediates hypoxia-induced inhibition of voltage-gated $\mathrm{K}^{+}$channel expression in pulmonary arterial myocytes. Am J Physiol Lung Cell Mol Physiol. 2008; 294:L309-318. [PubMed: 18065659]

149. Davie NJ, Schermuly RT, Weissmann N, Grimminger F, Ghofrani HA. The science of endothelin-1 and endothelin receptor antagonists in the management of pulmonary arterial hypertension: current understanding and future studies. Eur J Clin Invest. 2009; 39(Suppl 2):3849. [PubMed: 19335746]

150. Mair KM, MacLean MR, Morecroft I, Dempsie Y, Palmer TM. Novel interactions between the 5HT transporter, 5-HT1B receptors and Rho kinase in vivo and in pulmonary fibroblasts. Br J Pharmacol. 2008; 155:606-16. [PubMed: 18695640]

151. Semenza GL, Wang GL. A nuclear factor induced by hypoxia via de novo protein synthesis binds to the human erythropoietin gene enhancer at a site required for transcriptional activation. Mol Cell Biol. 1992; 12:5447-5454. [PubMed: 1448077]

152. Semenza GL. Pulmonary vascular responses to chronic hypoxia mediated by hypoxia-inducible factor 1. Proc Am Thorac Soc. 2005; 2:68-70. [PubMed: 16113471]

153. Prabhakar NR, Semenza GL. Adaptive and maladaptive cardiorespiratory responses to continuous and intermittent hypoxia mediated by hypoxia-inducible factors 1 and 2. Physiol Rev. 2012; 92:967-1003. [PubMed: 22811423]

154. Yu AY, Shimoda LA, Iyer NV, Huso DL, Sun X, McWilliams R, Beaty T, Sham JS, Wiener CM, Sylvester JT, et al. Impaired physiological responses to chronic hypoxia in mice partially deficient for hypoxia-inducible factor 1a. J Clin Invest. 1999; 103:691-696. [PubMed: 10074486]

155. Shimoda LA, Semenza GL. HIF and the lung: role of hypoxia-inducible factors in pulmonary development and disease. Am J Respir Crit Care Med. 2011; 183:152-156. [PubMed: 21242594]

156. Shimoda LA. 55th Bowditch Lecture: Effects of chronic hypoxia on the pulmonary circulation: Role of HIF-1. J Appl Physiol. 113:1343-1352. [PubMed: 22923506]

157. Iyer NV, Kotch LE, Agani F, Leung SW, Laughner E, Wenger RH, Gassmann M, Gearhart JD, Lawler AM, Yu AY, et al. Cellular and developmental control of $\mathrm{O}_{2}$ homeostasis by hypoxiainducible factor 1a. Genes Dev. 1998; 12:149-162. [PubMed: 9436976]

158. Brusselmans K, Compernolle V, Tjwa M, Wiesener MS, Maxwell PH, Collen D, Carmeliet P. Heterozygous deficiency of hypoxia-inducible factor-2a protects mice against pulmonary hypertension and right ventricular dysfunction during prolonged hypoxia. J Clin Invest. 2003; 111:1519-1527. [PubMed: 12750401]

159. Shimoda LA. Hypoxic regulation of ion channels and transporters in pulmonary vascular smooth muscle. Adv Exp Med Biol. 661:221-235. [PubMed: 20204733]

160. Abud EM, Maylor J, Undem C, Punjabi A, Zaiman AL, Myers AC, Sylvester JT, Semenza GL, Shimoda LA. Digoxin inhibits development of hypoxic pulmonary hypertension in mice. Proc Natl Acad Sci U S A. 2012; 109:1239-1244. [PubMed: 22232678] 


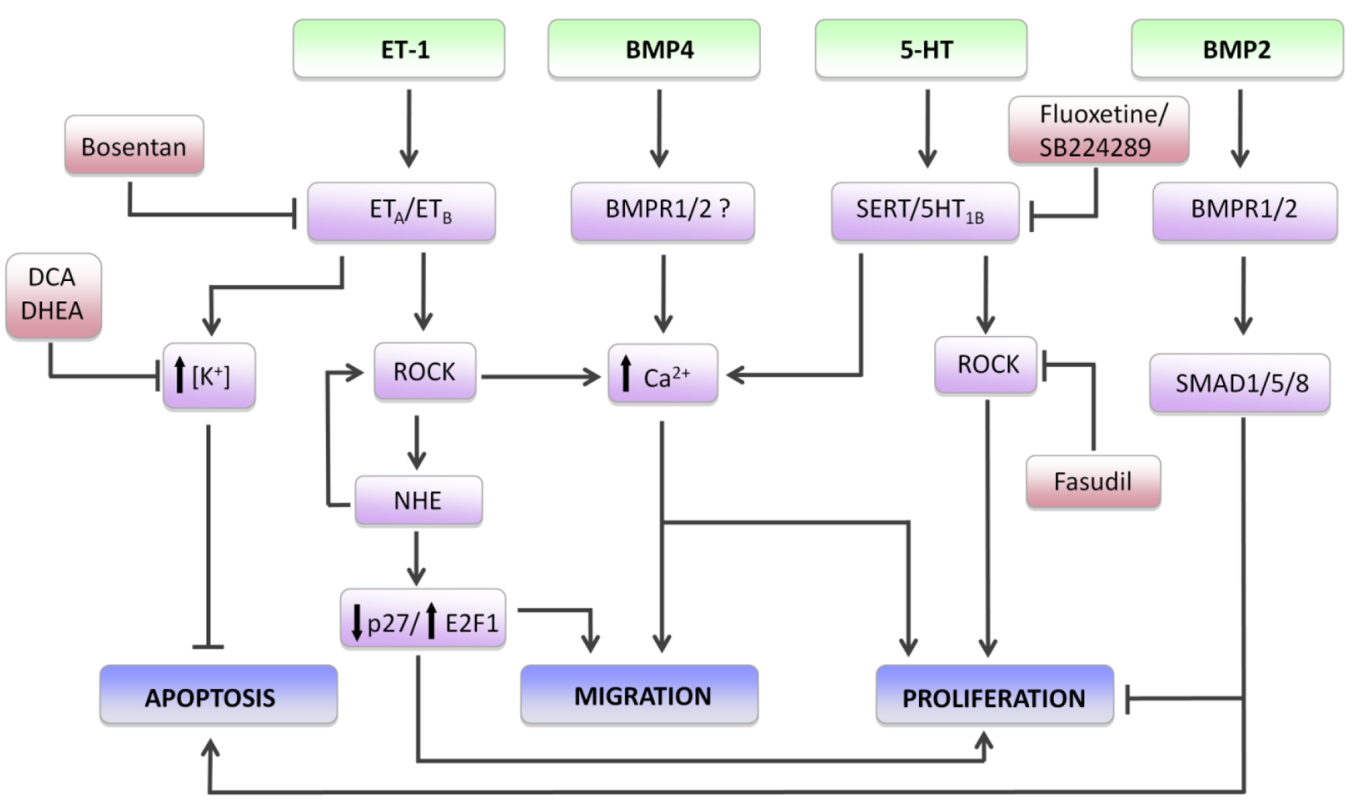

Fig. 1.

Some of the proposed signaling mechanisms in pulmonary arterial smooth muscle cells (PASMCs) leading to vascular remodeling during pulmonary hypertension. Agonists, including endothelin-1 (ET-1), bone morphogenetic proteins 2 and 4 (BMP2 and BMP4, respectively) and serotonin (5-HT) interact with membrane bound receptors or transporters (serotonin transporter, SERT). Activation of ET-1 receptors leads to increased intracellular $\mathrm{K}^{+}$concentration and inhibition of apoptosis, as well as activation of Rho kinase (ROCK) and downstream signaling through activation of the $\mathrm{Na}^{+} / \mathrm{H}^{+}$exchanger (NHE) and elevation of intracellular $\mathrm{Ca}^{2+}$. NHE increases ROCK activation and promotes migration and proliferation via downregulation of p27 and activation of the transcription factor E2F1. NHE has also been found to increase ROCK, suggesting potential feed-forward regulation. BMP4 and 5-HT both increase intracellular $\mathrm{Ca}^{2+}$, which is required for PASMC migration and proliferation. 5-HT-induced ROCK activity also leads to PASMC proliferation; whether this involves modulation of $\mathrm{Ca}^{2+}$ or $\mathrm{Ca}^{2+}$-independent pathways is unclear. BMP2 binding to type 1 and type 2 receptors (BMPR1 and BMPR2) activates SMAD1/5/8 signaling and represses proliferation and stimulates apoptosis. Pharmacological inhibitors (in red) reduce vascular remodeling by disrupting signaling at various points. 


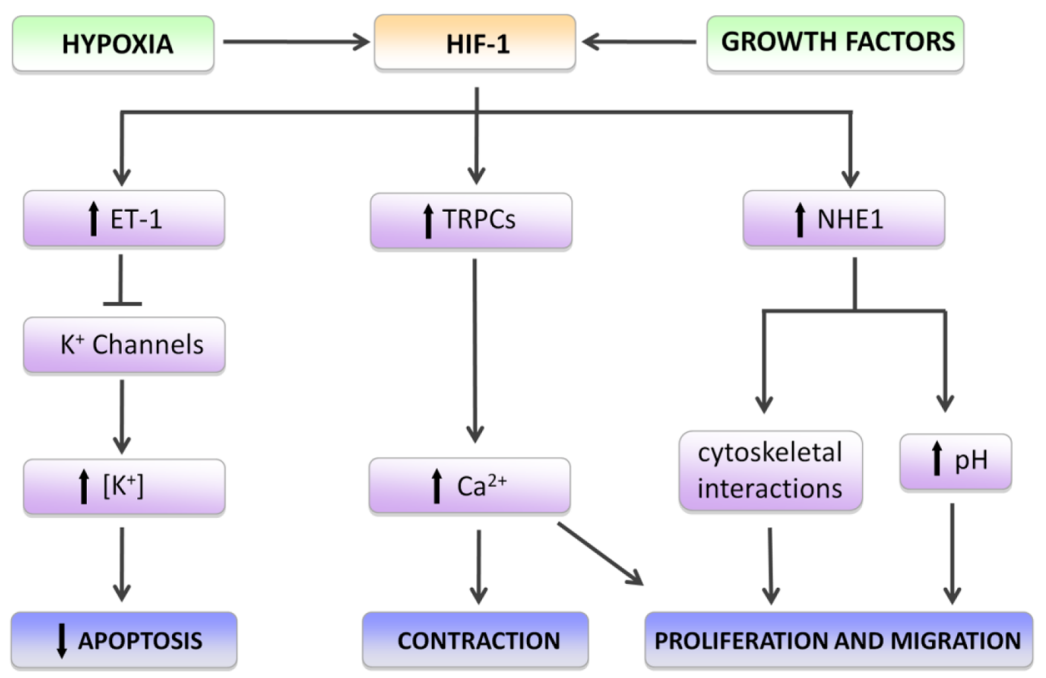

Fig. 2.

Hypoxia-inducible factor 1 (HIF-1) and pulmonary arterial smooth muscle responses during pulmonary hypertension. Exposure to hypoxia or growth factors activates HIF-1, leading to upregulation of endothelin-1 (ET-1), canonical transient receptor potential (TRPPC) proteins and $\mathrm{Na}^{+} / \mathrm{H}^{+}$exchanger isoform 1 (NHE1). Elevated ET-1 levels reduce $\mathrm{K}^{+}$channel expression and activity, allowing intracellular accumulation of $\mathrm{K}^{+}$and repression of apoptosis. Upregulation of TRPCs, which form $\mathrm{Ca}^{2+}$-permeable non-selective cation channels, increases intracellular calcium, facilitating contraction, proliferation and migration. Induction of NHE1 results in an alkaline shift in intracellular $\mathrm{pH}$ and enhanced tethering of the actin cytoskeleton to the membrane via NHE1/ezrin interactions, which promote cell shape changes required for proliferation and migration. 


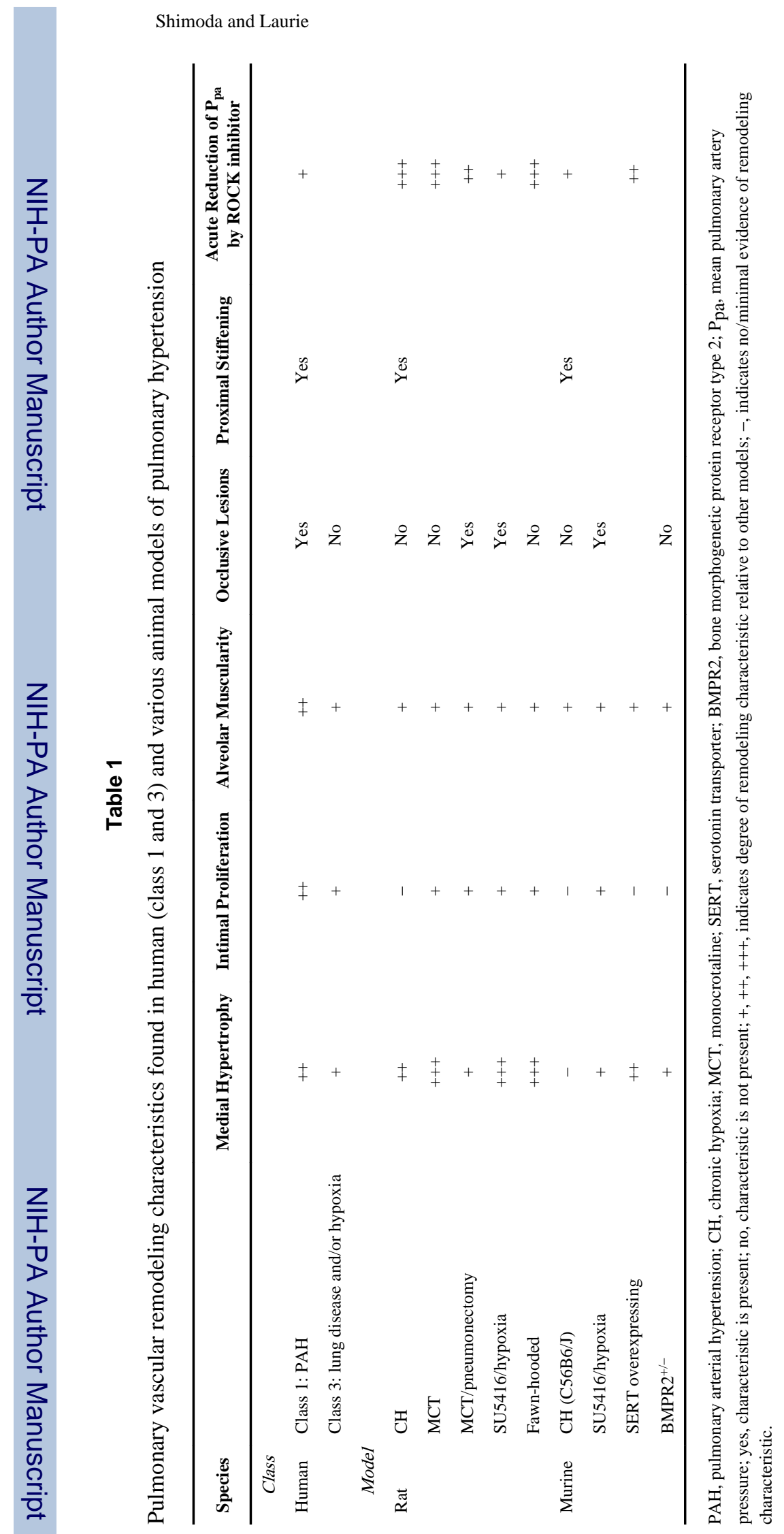

Page 21 